\title{
ANALISA HUKUM TERHADAP BENTURAN KEPENTINGAN DAN PENAWARAN TENDER DI PASAR MODAL
}

\author{
Marlisa Elfira \\ Mempawah \\ MarlisaElfira77@gmail.com
}

\begin{abstract}
The opportunity to make a profit is the most important factor for investors who participate in capital market transactions. With the legal status of "PT", this factor causes a violation of the principles of transparency and fairness in capital market transactions that have been potential to harm the rights of independent shareholders. In this study, the researcher will focus on the issue of how to identify the legal conflict of interest in the rights issue transaction conducted by PT CPRO and the implementation of the tender offer conducted by PT Philip Morris Indonesia for the remaining shares of PT HM Sampoerna Tbk. The type of research method that the researcher uses is a normative juridical study and by using a case approach. The results of this study are(1) Rights transactions carried out by CPRO, CPRO did not fully comply with existing regulations. (2) it can be seen that the acquisition that has occurred in PT. HM Sampoerna, Tbk did not cause much change, both in terms of marketing and for its employees. (3) the acquisition has made the rights of its employees more secure.
\end{abstract}

Keywords: Capital Market, Transparency and Fairness Violation, Independent Shareholder Rights, Tender Offer

\begin{abstract}
Abstrak: Peluang memperoleh keuntungan merupakan faktor terpenting bagi investor yang berpartisipasi dalam transaksi pasar modal. Dengan status hukum "PT", faktor ini menyebabkan pelanggaran prinsip transparansi dan kewajaran dalam transaksi pasar modal yang berpotensi merugikan hak pemegang saham independen. Dalam penelitian ini, peneliti akan focus pada persoalan bagaimana identifikasi hukum atas conflict of interest dalam transaksi right issue yang dilakukan oleh PT CPRO dan pelaksanaan tender offer yang dilakukan oleh PT Philip Morris Indonesia atas sisa saham PT HM Sampoerna Tbk. Adapun metode jenis penelitian yang peneliti gunakan adalah kajian yuridis normative dengan menggunakan pendekatan kasus (case approach). Hasil dari penelitian ini, ditemukan bahwa (1) transaksi HMETD yang dilakukan oleh CPRO, CPRO tidak sepenuhnya mematuhi peraturan yang ada. (2) dapat diketahui bahwa akuisisi yang telah terjadi pada PT. HM Sampoerna, Tbk tidak banyak menimbulkan perubahan baik itu dari segi pemasarannya maupun bagi karyawannya. (3) akuisisi yang telah dilakukan tersebut menjadikan hak para karyawannya lebih terjamin.
\end{abstract}

Kata Kunci: Pasar Modal, Pelanggaran Transparansi Dan Kewajaran, Hak Pemegang Saham Independen, Penawaran Tender

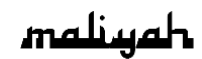

Jurnal Hukum Bisnis Islam

Volume 10, Nomor 01, Juni 2020

p-ISSN: 2088-4869/ e-ISSN: 2597-4351 


\section{Pendahuluan}

Pasar modal pada dasarnya merupakan pasar untuk berbagai instrumen keuangan atau surat-surat berharga jangka panjang yang bisa diperjualbelikan, sebagaimana terdapat dalam Undang-Undang No. 8 tahun 1995 tentang Pasar Modal yang berbunyi: "pasar modal adalah suatu kegiatan yang bersangkutan dengan penawaran umum dan perdagangan efek, perusahaan publik yang berkaitan dengan efek yang diterbitkannya, serta lembaga dan profesi yang berkaitan dengan efek."Tujuan berdirinya pasar modal adalah untuk memperkuat permodalan perusahaan yang bersangkutan. ${ }^{1}$ Pasar modal juga merupakan instrumen untuk mendorong dan menumbuhkan berbagai kegiatan ekonomi yang menciptakan lapangan kerja dan nilai tambah ekonomi serta meningkatkan pendapatan masyarakat dan nilai aset lembaga keuangan yang ikut berpartisipasi dalam pasar modal. ${ }^{2}$

Secara umum alasan pembentukan pasar modal adalah karena lembaga ini selain mampu menjalankan fungsi keuangan, lembaga ini juga mampu menjalankan fungsi ekonomi, yaitu pasar modal menyediakan fasilitas untuk memindahkan dana dari lender (pemilik dana) ke borrower (penerima dana) dengan menginvestasikan kelebihan dana yang dimiliki pemberi dana (lenders) dengan mengharapkan akan mendapatkan imbalan dari penyertaan dana tersebut. Sedangkan dari sisi kepentingan borrowers, dengan tersedianya dana dari pihak luar memungkinkan perusahaan tersebut

\footnotetext{
${ }^{1}$ Irham Fahmi mendefinisikan pasar modal adalah tempat di mana berbagai pihak khususnya perusahaan menjual saham (stocks) dan obligasi (bond) dengan tujuan dari hasil penjualan tersebut nantinya akan dipergunakan sebagai tambahan dana atau untuk memperkuat modal perusahaan, Irham Fahmi, Pengantar Pasar Modal (Bandung: Alfabeta, 2012). 55

2 Kementerian Keuangan RI Bapepam LK dan, Master Plan Pasar Modal Dan Industri Keuangan Non-Bank 2010-2014, n.d. 92-93
} 
melakukan pengembangan kegiatan bisnis tanpa harus menunggu dana dari hasil produksi perusahaan. ${ }^{3}$

Pada umumnya perusahan yang listing di pasar modal adalah perusahaan yang berbadan hukum Perseroan Terbatas (PT) ${ }^{4}$ yang dalam hal mencari keuntungan, tidak sedikit terjadi transaksi-transaksi yang menyimpang dari ketentuan hukum peraturan perundangan-undangan dan etika bisnis di pasar modal. Dengan mengharapkan return relative besar, terutama dalam sektor-sektor produktif, para usahawan cenderung mengabaikan, bahkan melanggar ketentuan bisnis dan mengakibatkan kerugian bagi yang lain. Hal tersebut didukung

3 Fungsi ini juga sebenarnya dilakukan oleh lembaga keuangan lainnya, perbankan. Tetapi ada perbedaannya, dana yang diperoleh dari pasar modal akan dimasukkan sebagai modal, sedangkan dana dari perbankan adalah dana passive (utang) yang akan jatuh tempo dalam waktu yang ditentukan. Sedangkan penyertaan (dana) melalui pasar modal berjangka panjang (lebih dari satu tahun), M. Irsan Nasarudin, Aspek Hukum Pasar Modal Indonesia (Jakarta: Kencana, 2008). 14

4 Sesuai dengan ketentuan yang terdapat dalam Pasal 1 angka 1 UU No. 40 Tahun 2007 tentang Perseroan Terbatas, yang dimaksud dengan PT adalah "badan hukum yang merupakan persekutuan modal, didirikan berdasarkan perjanjian, melakukan kegiatan usaha dengan modal dasar, yang seluruhnya terbagi dalamsaham dan memenuhi persyaratan yang ditetapkan oleh UndangUndang ini serta peraturan pelaksanaannya," modal suatu perusahaan dipresentasikan oleh kumpulan saham yang dimiliki pemilik modal perusahaan yang merupakan unsure yang sangat penting untuk menjalankan usaha perusahaan. Modal tersebut dapat berasal dari utang maupun modal sendiri. Para usahawan baik dalam dan luar negeri pada umumnya memilih PT dalam melakukan aktivitas usahanya, karena itu pertumbuhan dan perkembangan badan usaha yang berbentuk PT semakin hari semakin meningkat. Sebagai subjek hukum yang mampu mendukung hak dan kewajibannya, PT juga mampu mengembangkan dirinya sebagai institusi yang mempunyai kekayaan tersendiri terlepas dari pengurus dan pemegang saham. Dari sisi ekonomi, PT sebagai organisasi ekonomi yang mempunyai kedudukan sebagai badan hukum, mempunyai peluang yang sangat besar untuk dapat memanfaatkan potensi sumber dana masyarakat melalui mekanisme pasar modal, sehingga PT dapat menjadi wahana yang tepat untuk mencari laba. Bambang Riyatno, Dasar-Dasar Pembelanjaan Perusahaan (Yogyakarta: BPFE Yogyakarta, 2001).6 dan Agus Budiarto, Kedudukan dan Tanggung Jawab Pendiri Perseroan Terbatas, (Jakarta: Ghalia Indonesia, 2002), hal. 2.

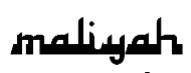

Jurnal Hukum Bisnis Islam

Volume 10, Nomor 01, Juni 2020

p-ISSN: 2088-4869/ e-ISSN: 2597-4351 
pula dengan semakin berkembang dan heterogennya pihak yang terlibat dalam transaksi di pasar modal, sehingga berpotensi menimbulkan benturan kepentingan (conflict of interest) dari masing-masing pihak, yang akhirnya menimbulkan sengketa. Tidak hanya sengketa, transaksi pasar modal pun mempunyai manfaat yaitu berkembangnya budaya keterbukaan di berbagai aspek, salah satunya adalah keterbukaan di bidang ekonomi. Khususnya berhubungan dengan masalah keuangan (financial disclosure) ${ }^{5}$.

Keterbukaan pada hal ini wajib terus berlangsung selama perusahaan go public. Dalam Pasal 1 angka 25 UndangUndang Pasar Modal telah disebutkan bahwa Prinsip Keterbukaan adalah pedoman umum yang mensyaratkan Emiten, Perusahaan Publik, dan Pihak lain yang tunduk pada undang-undang ini untuk menginformasikan kepada masyarakat dalam waktu yang tepat seluruh informasi Material mengenai usahanya atau efeknya yang dapat berpengaruh terhadap keputusan pemodal terhadap efek dimaksud dan/atau harga dari efek tersebut.

Tujuan keterbukaan ini untuk menciptakan mekanisme pasar yang efisien. Adapun prinsip keterbukaan mengenai fakta material yang baru adalah menyagkut mengenai peristiwaperistiwa yang dapat mempengaruhi harga saham, harus segera dilaporkan paling lambat 2 (dua) hari kerja. Peristiwaperistiwa yang dapat mempengaruhi harga saham antara lain

\footnotetext{
${ }^{5}$ Financial disclosure merupakan masalah mendasar dan mau tidak mau akan menjadi keharusan jika ingin menjadi good corporate citizen di tengah-tengah perekonomian dunia, manfaat yang jelas dari penerapan financial disclosure adalah (1) memungkinkan peningkatan penerimaan negara (pajak) melalui praktik pelaporan yang sehat dan terbuka; (2) mempercepat perkembangan pasar modal; (3) mempercepat terciptanya good management practices dan good corporate citizenship; dan (4) merupakan bentuk pertanggungjawaban publik oleh setiap pengusaha kepada masyarakat. Sebagaimana tercantum pada buku karangan I Putu Gede Ary Suta, Menuju Pasar Modal Modern (Jakarta: Sad Satria Bhakti, 2000).29
} 
Analisa Hukum Terhadap Benturan Kepentingan Dan Penawaran ...

tender offer, merger atau peleburan (consolidation) dan akuisisi. ${ }^{6}$

Tender offer (penawaran tender) adalah penawaran melalui Media Massa untuk memperoleh efek Bersifat Ekuitas dengan cara pembelian atau pertukaran dengan Efek lainnya. Efek bersifat Ekuitas adalah saham atau Efek yang dapat ditukar dengan saham atau Efek yang mengandung hak untuk memperoleh saham. ${ }^{7}$ Tender Offer ini bertujuan untuk melindungi kepentingan pemodal dari tindakan pengambilalihan perusahaan termasuk juga penyertaan dari suatu pihak yang dapat mengakibatkan hal-hal yang merugikan bagi para pemegang saham.

Sehingga sangat penting dilakukan bagi perusahaan go public. Oleh karena itu, peran pemerintah sebagai otoritas pembuat kebijakan dan peraturan perundang-undangan, hendaknya mampu mengawasi praktek dan transaksi ekonomi, khususnya di pasar modal agar sesuai dengan peraturan yang ada guna mendukung pertumbuhan ekonomi Indonesia, agar kepercayaan masyarakat, terutama investor dapat dipertahankan guna meningkatkan perekonomian dan berorientasi kepada pembangunan ekonomi yang wajar.

Hal tersebut dapat dilihat pada Pasal 33 ayat (4) UUD 1945.8 Merujuk dari hal tersebut, penulis mencoba untuk membahas tentang conflict of interest transaksi tertentu yang berkaitan dengan konversi utang menjadi saham melalui penawaran umum terbatas dengan HMETD (right issue) yang

\footnotetext{
${ }^{6}$ Bismar Nasution, Keterbukaan Dalam Pasar Modal (Jakarta: Fakultas Hukum Universitas Indonesia Program Pascasarjana, 2001). 176

${ }^{7}$ Keputusan Ketua BAPEPAM No. Kep-04/PM/2002. Peraturan No. Ix.F.1, Mengenai Penawaran Tender.

${ }^{8}$ Pasal ini berbunyi: "Perekonomian Nasional diselenggarakan berdasar atas demokrasi ekonomi dengan prinsip kebersamaan, efisiensi berkeadilan, berkelanjutan, berwawasan lingkungan, kemandirian, serta dengan menjaga keseimbangan kemajuan dan kesatuan ekonomi nasional."Abdul Manan, Hukum Ekonomi Syariah Dalam Perspektif Kewenangan Peradilan Agama (Jakarta: Kencana Prenada Media Grup, 2012).387
}

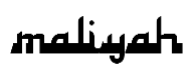

Jurnal Hukum Bisnis Islam 
dilakukan oleh PT. Central Proteinaprima (CPRO) ${ }^{9}$ dan tender offer yang dilakukan oleh Philip Morris Indonesia atas sisa saham di PT Handjaja Mandala Sampoerna Tbk atau biasa dikenal dengan PT HM Sampoerna Tbk dengan pokok masalah:

1. Bagaimana identifikasi hukum atas conflict of interest dalam transaksi right issue yang dilakukan oleh PT CPRO?

2. Bagaimana pelaksanaan tender offer yang dilakukan oleh PT Philip Morris Indonesia atas sisa saham PT HM Sampoerna Tbk?

\section{Conflict of Interest (Benturan Kepentingan) di Pasar Modal}

Kasus yang dibahas dalam tulisan ini bermula pada Juli 2007, di mana CPRO telah menyelesaikan pembelian aktiva tetap Grup Dipasena berdasarkan RUPS tanggal 6 Juli 2007. Dalam rangka pembelian tersebut, CPRO memperoleh pendanaan berupa pinjaman subordinasi dari PT Surya Hidup Satwa (SHS). ${ }^{10}$ Berdasarkan perjanjian novasi, kedudukan SHS selaku kreditur CPRO telah digantikan oleh PT Pertiwi Indonesia (PTPI). ${ }^{11}$ CPRO melakukan penambahan modal dengan HMETD (rignt issue) sebesar kurang lebih 17,5 milyar saham senilai Rp. 1,75 triliun pada Desember 2008 setelah memperoleh persetujuan RUPS-LB independen CPRO tanggal 28 Nopember 2008. Hasil HMETD tersebut akan dipergunakan CPRO untuk mengkonversi seluruh pinjaman subordinasi PTPI menjadi saham.

Dengan adanya konversi pinjaman subordinasi oleh PTPI, maka transaksi tersebut mengandung benturan kepentingan karena PTPI merupakan pihak yang terafiliasi

${ }^{9}$ Central Proteinaprima merupakan perusahaan pembudidayaan udang terbesar dunia yang terintegrasi.

10 Dalam memberikan pendanaan kepada CPRO tersebut, SHS mendapatkannya dari penjualan saham CPRO miliknya sebesar 4,4 milyar saham kepada Red Gragon. Dalam hal pembelian saham ini, Red Dragon memperoleh pendanaan dari menerbitkan obligasi yang dapat dikonversi menjadi saham pada juli 2007 sebesar 200 juta Dolar yang akan jatuh tempo pada tahun 2010 .

${ }^{11}$ Dimana hak dan kewajiban SHS beralih kepada PTPI. 
dengan Pemegang saham utama CPRO yaitu (PT Surya Hidup Satwa) SHS. CPRO, SHS dan PTPI dikendalikan oleh pihak yang sama yaitu Keluarga Jiaravanon. ${ }^{12}$ Dengan demikian, CPRO memiliki benturan kepentingan dengan PTPI dalam penggunaan hasil right issue. ${ }^{13}$ Selain itu, tindakan right issue yang dilakukan CPRO dinilai berpotensi merugikan, karena harga yang ditawarkan pada prospetus lebih tinggi dari harga saham CPRO -di mana sebagai saham yang dijadikan jaminan, harga saham CPRO jatuh ke kisaran Rp 140 per unit, sehingga nilai jaminan turun di bawah 250 persen dari nilai pokok obligasi yang beredar- di pasar yang berpotensi menurunkan kepemilikan saham Red Dragon jika pemegang saham tidak mengeksekusi haknya. ${ }^{14}$

Perdagangan efek yang wajar terjadi di pasar modal apabila penyelenggaraannya berlangsung wajar, di mana kekuatan penawaran atau permintaan dilakukan berdasarkan mekanisme pasar yang memiliki system penyampaian informasi akurat dan tepat waktu dan terhindar dari adanya kecurangan pihak yang memperoleh keuntungan dari ketidaktahuan pihak lain. ${ }^{15}$ Keterbukaan informasi ${ }^{16}$ adalah asas penting dalam system perdagangan efek di pasar modal yang harus dipatuhi oleh para pelaku usaha. Ketidakakuratan dan kecurangan dalam asas ini dapat menimbulkan kerugian

\footnotetext{
${ }^{12}$ Keluarga Jiaravanon melalui Red Dragon, PT Surya Hidup Satwa, dan perusahaan terafiliasi lainnya adalah pemegang 70 persen saham di CP Prima.Ibid.

13 Rizky Aliansyah, "Perlindungan Hukum Terhadap Pemegang Saham Minoritas Dalam Penawaran Umum Terbatas Yang Mengandung Benturan Kepentingan (Studi Kasus Penawaran Umum Terbatas Dengan HMETD PT Central Proteinaprima Tbk)" (Fakultas Hukum Universitas Indonesia, 2012).

14 vivanews, "Dalam Vivanews 'CP Prima Diminta Jelaskan Soal Right Issue,"” http://bisnis.news.viva.co.id/. 05/12/2014

${ }^{15}$ Yulfasni, Hukum Pasar Modal (Jakarta: Badan Penerbit IBLAM, 2005).69

${ }^{16}$ Menurut UUPM Pasal 1 ayat (7), informasi atau fakta material adalah fakta penting dan relevan mengenai peristiwa, kejadian, atau fakta yang dapat mempengaruhi harga efek pada bursa dan atau keputusan pemodal, calon pemodal, atau pihak lain yang berkepentingan atas informasi atau fakta tersebut.
}

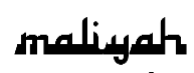

Jurnal Hukum Bisnis Islam 
bagi pihak lain dan mempengaruhi mekanisme pasar di pasar modal.

Adanya kepentingan untuk mendapatkan keuntungan oleh para pelaku usaha di pasar modal sering kali menimbulkan pertentangan (conflict of interest). Untuk itu dituntut adanya keseimbangan diantara dua kepentingan tersebut yang tercermin dalam prinsip yuridis yang menyatakan bahwa suatu keterbukaan (disclosure) dalam pasar modal tidak semata-mata "full" tetapi juga harus "fair". Beberapa transaksi pada kenyataannya merupakan praktik pasar modal yang "unfair" dan berpotensi besar mengandung benturan kepentingan (conflict of interest) beberapa pihak tertentu, terutama bagi para pemegang saham PT. Oleh karena itu, penerapan keterbukaan informasi da pemberdayaan pemegang independen merupakan sarana preventif dalam upaya mencegah terjadinya transaksi benturan kepentingan yang biasa menguntungkan mereka dan merugikan perseroan. ${ }^{17}$

Menurut Munir Fuady, suatu transaksi dapat dikatakan memiliki benturan kepentingan apabila: ${ }^{18}$

1. Adanya transaksi, yaitu suatu aktivitas atau kontrak dalam rangka memberikan dan/atau mendapat pinjaman, memperoleh, melepaskan, atau menggunakan aktiva, jasa, atau efek suatu perusahaan atau perusahaan terkendali, atau mengadakan kontrak sehubungan dengan aktivitas tersebut;

2. Adanya benturan kepentingan;

3. Benturan kepentingan tersebut adalah antara perusahaan dengan komisaris atau direktur atau pemegang saham utama;

4. Kepentingan yang berbenturan adalah kepentingan ekonomis; dan

${ }^{17}$ Nasarudin, Aspek Hukum Pasar Modal Indonesia.251

${ }^{18}$ Munir Fuady, Pasar Modal Modern: Tinjauan Hukum (Bandung: Citra Aditya Bakti, 1996).190-191 
5. Transaksi tersebut berpeluang merugikan perusahaan.

Dalam hal ini, berdasarkan peraturan Bapepam No.IX.E.1 tentang Benturan Kepentingan Transaksi Tertentu, ${ }^{19}$ yang dimaksud dengan benturan kepentingan adalah perbedaan antara kepentingan ekonomis perusahaan dengan kepentingan ekonomis pribadi anggota direksi, anggota komisaris, atau pemegang saham utama yang mempunyai benturan kepentingan atas transaksi tertentuyang terdapat dalam sejumlah modus transaksi yang terjadi. ${ }^{20}$ Dalam peraturan Bapepam tersebut (angka 2) disebutkan bahwa,

"transaksi yang mempunyai benturan kepentingan jika suatu transaksi di mana seorang direktur, komisaris, pemegang saham utama atau Pihak terafiliasi dari direktur, komisaris atau pemegang saham utama mempunyai Benturan Kepentingan, maka Transaksi dimaksud terlebih dahulu harus disetujui oleh para Pemegang Saham Independen atau wakil mereka yang diberi wewenang untuk itu dalam Rapat Umum Pemegang Saham sebagaimana diatur dalam peraturan ini. Persetujuan mengenai hal tersebut harus ditegaskan dalam bentuk akta notaril." 21

Dengan demikian, dapat dikatakan bahwa transaksi yang mengandung benturan kepentingan adalah transaksi yang memberikan keuntungan ekonomis antara perusahaan di satu pihak dengan pihak direksi, komisaris, atau pemegang saham

\footnotetext{
${ }^{19}$ Keputusan Ketuan Bapepam No.Kep-32/PM/2000 tentang Perubahan Peraturan No.IX.E. 1 tentang Benturan Kepentingan Transaksi Tertentu.

${ }^{20}$ Modus tersebut dapat berupa: (1) Penggabungan usaha, pembelian saham, peleburan usaha, atau pembentukan usaha patungan; (2) Perolehan kontrak penting; (3) Pembelian atau kerugian penjualan aktiva yang material; (4) Pengajuan tawaran untuk pembelian efek perusahaan lain;...dst; (14) Dan transaksi lain yang berindikasikan adanya benturan kepentingan Nasarudin, Aspek Hukum Pasar Modal Indonesia.247-248

${ }^{21}$ Selengkapnya dalam Lampiran Keputusan Ketua Bapepam No.KEP412/BL/2009 Peraturan No.IX.E.1 tentang Benturan Kepentingan transaksi tertentu.
} 
di lain pihak yang dilakukan atau difasilitasi oleh direksi/komisaris berdasarkan kekuasaannya.

Dengan kekuasaannya direksi/komisaris dapat
mengambil keputusan untuk bertransaksi demi kepentingannya atau kepentingan pihak lain, bukan demi perseroan. Untuk itu Bapepam mengharuskan persetujuan mayoritas pemegang saham independen yang ditegaskan dengan akta notaril. Jika transaksi tersebut dilakukan tanpa memenuhi persyaratan tersebut, ${ }^{22}$ maka tindakan direksi dan komisaris tersebut dapat diminta pertanggungjawabannya secara keperdataan. ${ }^{23}$ Untuk memperoleh persetujuan pemegang saham independen ini, dalam ketentuan angka 5, 9, 10, dan 11 peraturan Bapepam No. IX.E.1, harus diadakan RUPS dengan ketentuan:

1. RUPS pertama: (1) harus dihadiri pemegang saham independen yang mewakili lebih dari 50\% saham yang dimiliki oleh pemegang saham independen; dan (2) harus disetujui oleh pemegang saham independen yang mewakili lebih dari 50\% saham pemegang saham independen.

2. Apabila RUPS pertama tidak mencapai kuorum, maka RUPS kedua harus segera dilaksanakan: (1) dihadiri oleh pemegang saham independen yang mewakili lebih dari $50 \%$ saham yang dimiliki oleh pemegang saham

\footnotetext{
${ }^{22}$ Perlu dicatat bahwa tidak semua transaksi benturan kepentingan harus di memenuhi ketentuan tersebut di atas, dalam peraturan No.IX.E.1 angka (3) terdapat transaksi yang dikecualikan dari peraturan benturan kepentingan transaksi tertentu.

${ }^{23}$ Hal tersebut berdasarkan Ketentuan UU No. 8 Tahun 1995 tentang Pasar Modal Pasal 111 yang berbunyi: "Setiap Pihak yang menderita kerugian sebagai akibat dari pelanggaran atas Undang undang ini dan atau peraturan pelaksanaannya dapat menuntut ganti rugi, baik sendiri-sendiri maupun bersama-sama dengan Pihak lain yang memiliki tuntutan yang serupa, terhadap Pihak atau Pihak- Pihak yang bertanggung jawab atas pelanggaran tersebut." Dan diatur juga dalam UU No. 40 Tahun 2007 tentang Perseroan terbatas pasal 97 (3), yaitu: "Setiap anggota Direksi bertanggung jawab penuh secara pribadi atas kerugian Perseroan apabila yang bersangkutan bersalah atau lalai menjalankan tugasnya sesuai dengan ketentuan sebagaimana dimaksud pada ayat (2)."
} 
Analisa Hukum Terhadap Benturan Kepentingan Dan Penawaran ...

independen; (2) transaksi dimaksud disetujui oleh pemegang saham independen yang mewakili lebih dari $50 \%$ saham yang dimiliki oleh pemegang saham independen yang hadir.

3. Apabila dalam RUPS kedua, kourum juga belum tercapai, maka rapat ketiga dapat diambil keputusan setelah terpenuhinya: (1) telah mendapatkan persetujuan dari Bapepam; (2) telah diumumkan kepada masyarakat; (3) dan disetujui oleh pemegang saham independen yang mewakili lebih dari 50\% saham yang dimiliki oleh pemegang saham independen yang hadir.

4. Dan apabila transaksi tersebut tidak mendapatkan persetujuan pemegang saham independen untuk RUPS yang ketiga, maka rencana transaksi tersebut tidak dapat diajukan kembali dalam waktu 12 bulan sejak tanggal keputusan ditolak.

5. Pemberitahuan tentang RUPS untuk menyetujui transaksi tersebut harus diumumkan ${ }^{24}$ dan salinannya disampaikan kepada Bapepam selambat-lambatnya dua hari setelah diumumkan.

Berdasarkan peraturan-peraturan tersebut, dapat dikatakan bahwa pengaturan benturan kepentingan transaksi tertentu ini adalah upaya perlindungan hukum para memegang modal (investor), di mana hal sejalan dengan prinsip good corporate governance (GCG) yang menghormati hak pemegang

24 Pengumuman tersebut setidaknya meliputi: (1) uraian mengenai transaksi (objek, nilai, hubungan para pihak, sifat dari benturan kepentinga para pihak), (2) ringkasan laporan penilai (identitas pihak, obyek penilaian, tujuan penilaian, asumsi, pendekatan dan metode penilaian, kesimpulan nilai, dan pemdapat kewajaran atas transaksi), (3) keterangan tentang RUPS, (4) penjelasan pertimbangan dan alasan dilakukannya transaksi, (5) rencana perusahaan, data perusahaan dan informasi lain, (6) pernyataan dewan komisaris dan direksi tentang kebenaran informasi material yang diumumkan, (7) ringkasan laporan tenaga ahli atau komunikasi independen jika dianggap perlu. Peraturan Bapepam No.IX.E.1 Lampiran keputusan Bapepam-LK No.Kep521/BL/2008 tentang Transaksi Afiliasi dan Benturan Kepentingan Transaksi Tertentu angka 4. 
saham, memberikan perlakuan yang sama di antara para pemegang saham, dan melindungi kepentingan saham minoritas. ${ }^{25}$

\section{Pelanggaran Ketentuan Benturan Kepentingan transaksi Tertentu oleh PT CPRO}

Sebelum menganalisis benturan kepentingan transaksi tertentu yang dilakukan oleh CPRO, ada baiknya penulis membahas tentang HMETD (right issue) di pasar modal. Berdasarkan Peraturan Bapepam No. IX.D.1: Keputusan Ketua bapepam No. Kep-26/PM/2003 17 Juli 2003, yang dimaksud dengan HMETD atau right issue adalah hak yang melekat pada saham yang memungkinkan para pemegang saham yang ada untuk membeli efek baru, termasuk saham, efek yang dapat dikonversikan menjadi saham atau waran, sebelum ditawarkan kepada pihak lain, di mana hak tersebut wajib dapat dialihkan. Disini, setiap pemegang saham diberi HMETD sebanding dengan persentase kepemilikan mereka. Penawaran umum dengan HMETD harus mengadakan RUPS dan wajib mengumumkan informasi sebagaimana ditentukan dalam peraturan Bapepam ini selambat-lambatnya 28 hari sebelum RUPS dilaksanakan.

Tujuan penerbitan HMETD umumnya adalah untuk meningkatkan (menambah) jumlah modal perusahaan. UU No. 40 Tahun 2007 tentang Perseroan Terbatas Pasal 43 menyebutkan bahwa seluruh saham yang dikeluarkan untuk penambahan modal harus ditawarkan terlebih dahulu kepada pemegang saham yang ada. Kewajiban tersebut dimaksudkan untuk melindungi kepemilikan pemegang saham suatu perusahaan agar tidak mengalami dilusi (penurunan persentase kepemilikan saham) apabila perusahaan tersebut bermaksud untuk menambah modalnya. Namun demikian, dalam menjalankan kegiatan usahanya seringkali suatu perusahaan merasakan kebutuhan untuk mengeluarkan saham kepada pihak-pihak di luar pemegang saham, seperti ketika

${ }^{25}$ Nasarudin, Aspek Hukum Pasar Modal Indonesia.245 
perusahaan hendak menerbitkan saham bagi para karyawan, menerbitkan saham kepada kreditur karena tidak mampu melunasi hutangnya dengan cash, dan sebagainya. Karena adanya kebutuhan-kebutuhan tersebut, maka UUPT memberikan jalan keluar bahwa kewajiban untuk menawarkan terlebih dahulu kepada pemegang saham yang ada tersebut tidak berlaku dalam hal pengeluaran saham ditujukan kepada karyawan perusahaan, kepada pemegang efek yang dapat dikonversi menjadi saham, atau dilakukan dalam rangka restrukturisasi. Peraturan mengenai ketentuan penerbitan HMETD, selain terdapat dalam UUPT, UUPM, Peraturan Bapepam No.IX.D.1, juga diatur dalam Peraturan Bapepam No.IX.D.2 tentang Pedoman Mengenai Bentuk dan Isi Pernyataan Pendaftaran Dalam Rangka Penerbitan HMETD dan Peraturan No.IX.D.3 tentang Pedoman Mengenai Bentuk dan Isi Prospektus Dalam Rangka Penerbitan HMETD.

Pada prinsipnya right issue merupakan bagian tidak terpisahkan dari strategi perusahaan dalam rangka memperkuat daya saing (competitive position). Namun demikian, hal tersebut tidak selalu diterima dengan baik oleh investor (pemegang saham), sehingga terkadang dalam penerbitan HMETD, bagi investor yang tidak tertarik dengan saham baru dengan HMETD, ia tidak akan mengambil bagiannya, yang akhirnya mengakibatkan terjadinya dilusi. ${ }^{26}$ Dalam hal ini, Pertimbangan CPRO dalam melakukan rights issue adalah untuk mengurangi beban hutang yang ada. ${ }^{27}$ Melalui konversi hutang menjadi saham, CPRO menerbitkan saham baru kepada kreditur sebagai bentuk pembayaran atas kewajibannya. Hal ini dilakukan karena CPRO tidak mampu melunasi kewajibannya kepada kreditur secara tunai. Akibat dari dilakukannya konversi tersebut, hutang perusahaan akan berkurang, modal disetor perusahaan bertambah, pihak kreditur berubah menjadi pemegang saham dan kepemilikan

\footnotetext{
${ }^{26}$ Hendy M, Go Public: Pendanaan Dan Peningkatan Nilai Perusahaan (Jakarta: Elex Media Komputindo, 2008).220

${ }^{27}$ http://bisnis.news.viva.co.id/ 5/12/2014 2:02 pm.
} 
pemegang saham yang ada menjadi terdilusi.Akan tetapi, kenyataannya adalah pergerakan saham CPRO turun secara tidak wajar, sehingga menarik perhatian otoritas untuk mencermati pergerakan harga saham CPRO tersebut. ${ }^{28}$ Berdasarkan pemeriksaan yang dilakukan Bapepam, terdapat pelanggaran yang dilakukan oleh CPRO, yaitu: ${ }^{29}$

1. Aksi korporasi HMETD yang dilakukan setelah persetujuan RUPSLB ternyata tidak memenuhi kuorum sesuai ketentuan Bapepam, dimana RUPSLB baru bisa dilaksanakan apabila dihadiri oleh pemegang saham independen yang mewakili dari 50\% dari seluruh saham yang dimiliki pemegang saham independen. ${ }^{30}$

2. Keterlambatan CPRO selama 22 hari dalam mengungkapkan adanya addendum perjanjian utang piutang dengan SHS (pemegang Saham CPRO sebesar 45.14\%), sehingga Bapepam memberikan sanksi administrative sebesar Rp. 22 juta karena melanggar peraturan Bapepam No. X.K.1 tentang Keterbukaan Informasi Material. ${ }^{31}$

28 Berdasarkan data BEI, pada periode 3-28 November 2008, harga saham Central Proteinaprima melemah Rp 28 (29,1 persen) dari level Rp 96 menjadi Rp 68 per unit. Sebelumnya, PT Bursa Efek Indonesia (BEI) sempat menghentikan sementara perdagangan (suspend) hak memesan efek terlebih dahulu (HMETD) CPRO sejak sesi pertama transaksi Jumat 19 Desember 2008. Kepala Divisi Perdagangan Saham BEI, Supandi mengatakan, penghentian sementara transaksi HMETD CPRO mempertimbangkan informasi yang masih perlu diklarifikasi oleh bursa, terutama terkait HMETD itu. Ibid.

${ }^{29}$ Pelanggaran yang disebutkan merupakan hasil analisis penulis setelah melihat hasil pemeriksaan Bapepam dan data-data lain terkait kasus Benturan Kepentingan Transaksi Tertentu yang dilakukan oleh CPRO.

${ }^{30}$ Bapepam-LK, Press Release Badan Pengawad Pasar Modal dan Lembaga keuangan 13 Maret 2009 Aliansyah, "Perlindungan Hukum Terhadap Pemegang Saham Minoritas Dalam Penawaran Umum Terbatas Yang Mengandung Benturan Kepentingan (Studi Kasus Penawaran Umum Terbatas Dengan HMETD PT Central Proteinaprima Tbk).”91

${ }^{31}$ Berdasarkan peraturan Bapepam No.IX.D.1, pengumuman informasi tambahan atau perubahan harus dilakukan selambat-lambatnya dua hari setelah transaksi tersebut dilakukan. Hal tersebut sesuai dengan ketentuan UUPM Pasal 86 (1) dan Peraturan Bapepam No.X.K.1. 
3. Penambahan modal serta konversi piutang PTPI menjadi CPRO tidak sah karena tidak memenuhi kuorum pemegang saham independen, yaitu hanya sebanyak $45.97 \%$ dari jumlah saham yang dimiliki pemegang saham independen. ${ }^{32}$ Padahal utang piutang antara SHS dengan CPRO merupakan transaksi benturan kepentingan, karena dana hasil right issue untuk membiayai pembelian aktiva tetap grup Dipasena pada Juli 2007 senilai Rp 17 triliun yang kemudian perjanjian tersebut dinovasi kepada PTPI sehingga PTPI yang juga berkepentingan atas saham CPRO. 33

4. Selain itu, dengan ditetapkannya perdagangan saham yang hanya berlangsung lima hari kerja (15-19 Desember 2008), membuat para pemegang saham minoritas berupaya keras untuk mengumpulkan dana untuk membeli saham baru yang diterbitkan saat itu agar dapat tetap mempunyai porsi saham yang sama seperti sebelumnya. Dengan demikian terjadinya dilusi kepemilikan saham yang dimiliki oleh pemegang saham akan menjadi sangat besar yang tentunya berpengaruh terhadap perannya dalam pengendalian perusahaan.

\section{Konsep Penawaran Tender (Tender Offer)}

\footnotetext{
32 Sedangkan dalam akta berita acara RUPS, diketahui jumlah pemegang saham independen yang hadir adalah 55,48\% dari seluruh saham yang dimiliki oleh Pemegang saham independen. Namun berdasarkan hasil pemeriksaan Bapepam terbukti bahwa terdapat 9,51\% dalam kuorum kehadiran RUPS tersebut adalah pemegang saham non-independen. Kelalaian direksi dalam pencatatan akta tersebut merupakan pelanggaran terhadap salah satu hak individual (personal right) pemegang saham, yaitu untuk menghadiri dan memberikan suara dalam RUPS. Dimana dalam hal ini, seluruh pemegang saham independen CPRO seharusnya mempunyai kesempatan untuk dapat memberikan suara di RUPS selanjutnya apabila kuorum RUPS I tidak terpenuhi.

${ }^{33}$ Sifat transaksi benturan kepentingan tersebut dapat dilihat dari terdapatnya hubungan afiliasi antara Direktur Utama CPRO juga menjabat sebagai Direktur Utama PTPI dan Gunawan Taslim selaku Direktur CPRO juga menjabat sebagai Direktur PTPI.
}

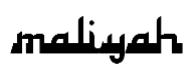

Jurnal Hukum Bisnis Islam 
Kasus yang dibahas dalam hal ini dimulai pada 14 Maret 2005, Perusahaan Rokok asal Amerika Serikat PT Philip Morris Indonesia mengakuisisi $40 \%$ saham PT HM Sampoerna Tbk. Philip Morris membeli 1.753.200.000 lembar saham HMSP dengan harga Rp 10.600 per saham sedangkan pada penutupan perdagangan saham saat itu di Bursa Efek Jakarta (BEJ) saham HMSP ada di level Rp 8.850 per saham. ${ }^{34}$ Jumlah akuisisi yang dilakukan oleh PT Philip Morris Indonesia yaitu sebesar US\$ 2 miliar atau sekitar RP 18,6 triliun untuk 40\% kepemilikan saham HMSP. ${ }^{35}$ PT Philip Morris Indonesia merupakan bagian dari grup Philip Morris International. ${ }^{36}$ Philip Morris adalah perusahaan rokok Amerika Serikat terbesar di dunia dari jumlah penjualan.

Perusahaan ini bernaung di bawah group Altria yang juga memproduksi makanan dan minuman. ${ }^{37}$ Phillip Morris memproduksi rokok terkenal antara lain Marlboro, Virginia Slims, Benson, Hedges dan West. ${ }^{38}$ Sedangkan HMSP merupakan perusahaan rokok terbesar ketiga di Indonesia. ${ }^{39}$ Setelah akuisisi saham-saham tersebut terlaksana PT Philip Morris Indonesia akan melakukan tender untuk sisa saham di HMSP sebagaimana disyaratkan dalam Undang-Undang yang berlaku.

Berdasarkan peraturan Bapepam, setiap pembelian saham lebih dari 20 persen harus dilakukan tender offer.40Pasca akusisi, PT Philip Morris Indonesia melanjutkan pembelian saham HMSP dari pemegang saham publik melalui

\footnotetext{
${ }^{34}$ Tambunan and Andy Porman, Menilai Harga Wajar (Stock Valuation)

(Jakarta: Gramedia, 2008).42

${ }^{35}$ Ibid.

${ }^{36}$ Tengku Lia Chairani, “'Dampak Akuisisi Antara PT. Philip Morris Indonesia Dengan PT HM Sampoerna Tbk Terhadap Status Karyawan PT HM Sampoerna Tbk Ditinjau Dari Segi Hukum Dagang," (Fakultas Hukum Universitas

Sumatera Utara, 2006).91

${ }^{37}$ Ibid.

${ }^{38}$ Ibid.

${ }^{39}$ Ibid. 85

${ }^{40}$ Peraturan Bapepam Nomor IX.H.1 angka 1 huruf d
} 
tender offer pada harga yang sama dengan harga pembelian dari keluarga Sampoerna. ${ }^{41}$ PT Philip Morris Indonesia melakukan tender offer atas saham yang dimiliki publik sebanyak 2.539.867.705 saham atau sebanyak $58 \%$ dari saham HMSP. ${ }^{42}$ Sehingga pada 18 Mei 2005 penawaran tender umum ditutup, dan berdasarkan pemberitahuan BEJ pada tanggal 3 Juni 2005, Kustodian Sentral Efek Indonesia (KSEI) mengesahkan bahwa PT Philip Morris Indonesia telah memiliki $58 \%$ saham Sampoerna. ${ }^{43}$ Jika ditambah dengan 40\% saham yang telah dimiliki sebelumnya artinya PT Phillip Morris Indonesia memiliki 98\% saham Sampoerna dan menjadikanya pemegang saham mayoritas.

\section{Tender Offer (Penawaran Tender) di Pasar Modal}

Tender offer dipersyaratkan oleh perundang-undangan dalam hal suatu pihak akan melakukan tindakan tertentu di pasar modal, yaitu jika dia ingin mendapatkan effek dalam jumlah, presentase yang besar, atau dengan perolehan efek tersebut peranannya dalam perusahaan tersebut menjadi penting. Sebagian orang mengatakan bahwa sebenernya suatu tender offer merupakan suatu "peperangan yang dihalalkan" seperti juga stabilitas harga pada waktu penawaran yang merupakan manipulasi pasar yang dilegalisir. ${ }^{44}$ Pasal 83 Undang-Undang Pasar Modal Nomor 8 Tahun 1995 mempersyaratkan agar suatu tender offer ${ }^{45}$ di pasar modal haruslah mematuhi ketentuan-ketentuan dan syarat tentang: 46

1. Keterbukaan

2. Kewajaran

3. Pelaporan

\footnotetext{
${ }^{41}$ Tambunan and Porman, Menilai Harga Wajar (Stock Valuation).44

42 Ibid.

${ }^{43}$ Ibid.

${ }^{44}$ Fuady, Pasar Modal Modern: Tinjauan Hukum.193

45 Pada Undang-Undang Nomor 8 Tahun 1995 Tentang Pasar Modal Menggunakan Istilah "Penawaran Tender,".

46 Ibid.
} 
Tender offer harus dilakukan karena dengan pembelian suatu efek yang dapat merubah suatu pengendalian suatu perusahaan, dalam hal ini perusahaan target, maka akan terjadi:

1. Pengendali perusahaan akan berubah, yang mungkin diikuti dengan perubahan policy lainnya dalam perusahaan yang bersangkutan.

2. Dapat menyebabkan berkurangnya jumlah pemegang saham secara signifikan.

3. Atau bahkan karena berkurangnya jumlah pemegang saham, ada kemungkinan perusahaan yang bersangkutan tidak lagi memenuhi syarat sebagai perusahaan publik, sehingga dengan demikian terjadilah proses go private dari perusahaan yang bersangkutan. ${ }^{47}$

Konsep istilah tender offer lainnya adalah "A public offer to purchase stock of a corporation from its shareholders at a certain price within a stated time limit, often in an effort to win control of the company". ${ }^{48}$ Tender offer dibagi menjadi 2 (dua), antara lain: 49

1. Tender offer yang sifatnya wajib; dan

2. Tender offer yang sifatnya sukarela.

Tender offer wajib adalah penawaran untuk membeli sisa saham Perusahaan yang wajib dilakukan oleh Pengendali baru sehingga yang dimiliki oleh Pengendali baru berjumlah paling banyak $80 \%$ (delapan puluh persen) dari jumlah saham Perusahaan yang telah disetor penuh. ${ }^{50}$

Tender offer sukarela adalah penawaran yang dilakukan oleh Pihak untuk memperoleh Efek Besifat Ekuitas yang diterbitkan oleh Perusahaan Sasaran dengan cara pembelian

\footnotetext{
${ }^{47}$ Ibid.

${ }^{48}$ Roger Leroy Miller and Frank B. Cross, Business Law:Alternate Edition (Twelfth Edition) (Cengage Learning, 2013).741

49 pada ekonomi Okezone, "“Tender Offer," http://economy.okezone.com/.

50 Peraturan Bapepam Nomor IX.H.1 angka 1 huruf e
} 
atau pertukaran dengan Efek lainnya melalui Media Massa. ${ }^{51}$ Transaksi dalam rangka tender offer sukarela dapat dilakukan baik di dalam ruangan maupun di luar Bursa Efek. Transaksi di luar Bursa Efek adalah transaksi yang dilaksanakan antara pembeli dan penjual secara langsung. 52

Pelaksanaan tender offer tidak lepas dari pengambilalihan perusahaan terbuka. Pengambilalihan adalah tindakan, baik langsung maupun tidak langsung, yang mengakibatkan perubahan Pengendali. ${ }^{53}$ Sebagai pihak yang melakukan pengambilalihan sebanyak $25 \%$ saham atau lebih, pihak tersebut wajib melakukan tender offer, kecuali terhadap: ${ }^{54}$

1. Saham yang dimiliki pemegang saham yang telah melakukan transaksi Pengambilalihan dengan Pengendali baru;

2. Saham yang dimiliki Pihak lain yang telah mendapatkan penawaran dengan syarat dan kondisi yang sama dari Pengendali baru;

3. Saham yang dimiliki Pihak lain yang pada saat bersamaan juga melakukan Penawaran Tender Wajib atau Penawaran Tender Sukarela atas saham Perusahaan yang sama;

4. Saham yang dimiliki Pemegang Saham Utama; dan

5. Saham yang dimiliki oleh Pengendali lain Perusahaan tersebut.

Terdapat beberapa pengecualian untuk tidak melakukan tender offer, antara lain: ${ }^{55}$

1. Pengambilalihan mengakibatkan Pengendali baru memiliki saham pada Perusahaan dengan jumlah lebih besar dari 80\% (delapan puluh persen) dari seluruh saham Perusahaan yang telah disetor penuh;

\footnotetext{
51 Peraturan Bapepam Nomor IX.F.1 angka 1 huruf a butir 3)

52 Peraturan Bapepam Nomor IX.F.1 angka 1 huruf b

53 Peraturan Bapepam Nomor IX.H.1 angka 1 huruf d

54 Peraturan Bapepam Nomor IX.H.1 angka 3 huruf a butir 2)

55 Peraturan Bapepam Nomor IX.H.1 angka 5 huruf a
} 
2. Pengambilalihan terjadi karena perkawinan atau pewarisan;

3. Pengambilalihan oleh Pihak yang sebelumnya tidak memiliki saham Perusahaan yang terjadi karena pemebelian atau perolehan saham Perusahaan dalam jangka waktu setiap 12 (dua belas) bulan, dalam jumlah paling banyak 10\% (sepuluh persen) dari jumlah saham yang berdar dengan hak suara yang sah.

4. Pengambilalihan terjadi karena pelaksanaan tugas dan wewenang dari badan atau lembaga pemerintah atau negara berdasarkan undang-undang;

5. Pengambilalihan terjadi karena pembelian langsung saham yang dimiliki dan/atau dikuasai badan atau lembaga pemerintah atau negara;

6. Pengambilalihan terjadi karena penetapan atau putusan pengadilan yang telah mempunyai hukum tetap;

7. Pengambilalihan terjadi karena penggabungan usaha, pemisahan usaha, peleburan usaha, atau pelaksanaan likuidasi pemegang saham;

8. Pengambilalihan terjadi karena adanya hibah yang merupakan penyerahan saham tanpa perjanjian untuk memperoleh imbalan dalam bentuk apapun;

9. Pengambilalihan terjadi karena adanya jaminan utang tertentu yang telah di tetapkan dalam perjanjian utangpiutang, serta jaminan utang dalam rangka restrukturisasi perusahaan yang ditetapkan oleh badan atau lembaga pemerintah atau negara berdasarkan undang-undang;

10. Pengambilalihan terjadi karena perolehan saham sebagai pelaksanaan Peraturan Nomor IX.D.1 dan Peraturan Nomor IX.D.4;

11. Pengambilalihan terjadi karena pelaksanaan kebijakan badan atau lembaga pemerintah atau negara;

12. Penawaran tender wajib, yang apabila dilaksanaan akan bertentangan dengan peraturan perundang-undangan; dan

13. Pengambilalihan terjadi karena pelaksanaan Penawaran Tender Sukarela berdasarkan Peraturan nomor IX.F.1. 
Adapun sanksi yang dikenakan apabila tidak melakukan tender offer, adalah sebagai berikut:

1. Pembatalan transaksi dan mewajibkan Pengendali baru untuk (a) membayar denda dan (b) mengembalikan saham kepada Pihak yang menjadi lawan transaksi dan mengganti kerugian yang timbul; atau

2. Denda dan kewajiban melakukan Penawaran Tender Wajib.

Setiap pihak yang akan melakukan suatu tender offer harus pula memperhatikan prosedur yang berlaku untuk tender offer tersebut, yaitu: 56

1. Tahap Pengumuman Rencana Penawaran Tender

2. Tahap Penyampaian Pernyataan Penawaran Tender

3. Tahap Efektifnya Masa Penawaran Tender

4. Tahap Pengumuman Pernyataan Penawaran Tender

5. Tahap Bantahan dari Direksi/Komisaris Perusahaan Target

6. Tahap Berakhirnya Masa Penawaran Tender

7. Tahap Penyelesaian Transaksi

8. Tahap Laporan Akhir

Harga penawaran dalam suatu tender offer adalah sebagai berikut: 57

1. Harus lebih tinggi dari harga penawaran tender tertinggi yang diajukan sebelumnya oleh pihak yang sama dalam jangka waktu 180 hari sebelum pelaksanaan pengumuman tentang rencana penawaran tender.

2. Harus lebih tinggi dari harga pasar tertinggi atas efek yang bersangkutan di Bursa Efek dalam jangka waktu 90 hari terakhir sebelum dilakukan pengumuman tentang rencana penawaran tender.

Peraturan tender offer di pasar modal manapun diarahkan untuk memberikan perlindungan kepada pemegang

\footnotetext{
${ }^{56}$ Jasso Winarto, Pasar Modal Indonesia, Retrospeksi Lima Tahun Swastanisasi BEJ, Cet I, (Jakarta: PT. Jayakarta Agung Offset, 1997). 198

57 Asril Sitompul, Pasar Modal, Penawaran Umum Dan Permasalahannya (Bandung: PT Citra Aditya Bakti, 2000).276
} 
saham publik. Perlindungan dimaksud meliputi hal-hal sebagai berikut: pertama, bahwa offeror (pihak calon pembeli) adalah pihak yang baik dari sisi keuangan maupun integritas yang dimilikinya. Kedua, bahwa harga yang ditawarkan berlaku untuk semua pihak, baik offeree (pihak penjual) maupun pemegang saham publik. Dalam hal ini yang perlu dicermati adalah penyebaran informasi yang merata kepada masyarakat. Ketiga, bahwa informasi tentang perusahaan sasaran harus mengandung kebenaran. Keempat, bahwa harga yang ditawarkan oleh pembeli harus lebih tinggi dari harga tertinggi di bursa efek dalam jangka waktu 90 hari terakhir. Kelima, bahwa proses tender offer harus transparan, sesuai dengan peraturan Bapepam dan oleh karenanya harus diaudit oleh akuntan publik. Keenam, untuk mencegah terjadinya insider trading, pihak offeror dilarang melakukan transaksi dalam jangka waktu 15 hari sebelum pengumuman tender offer sampai dengan selesai. Jadi inti dari proses tender offer ini adalah fairness (kewajaran), transparansi, dan perlindungan kepada masyarakat. 58

\section{Pelaksanaan Tender Offer oleh PT Philip Morris Indonesia}

Berdasarkan surat yang dikirim dari KSEI Nomor KSEI3276/JKS/0405 perihal Pelaksanaan Tender Offer atas saham PT Hanjaya Mandala Sampoerna Tbk (HMSP), pelaksanaan tender offer atas saham HMSP sudah sesuai dengan peraturan yang berlaku. Berikut analisis pelaksanaan tender offer yang dilakukan oleh PT Philip Morris Indonesia atas saham HMSP:

1. Tahap Pengumuman Rencana Penawaran Tender

Pengumuman rencana penawaran tender ini dilakukan lewat minimal dua surat kabar. Pengumuman ini antara lain memuat:

a. Identitas pihak pelaku penawaran tender.

b. Persyaratan khusus penawaran tender.

${ }^{58}$ Suta, Menuju Pasar Modal Modern.441 
c. Pernyataan bahwa pihak penawar tender telah mempunyai dana yang cukup, pernyataan mana dibuat akuntan, bank dan penjamin emisi efek.

Teks pengumuman rencana tender offer tersebut wajib disampaikan kepada Bapepam dan kepada perusahaan target dalam waktu selambat-lambatnya dua hari kerja sebelum dimuatnya teks yang bersangkutan dalam dua surat kabar tersebut. Banyak konsekuensi hukum yang terjadi dapat diumumkannya rencana tender offer tersebut, antara lain sekali pengumuman telah dilangsungkan, maka tender offer tersebut tidak dapat dicabut atau dibatalkan kembali.

Pada kasus ini PT Philip Morris Indonesia telah mengumumkan melalui media massa tanggal 18 April 2005 dan surat yang diterima dari PT Bahana Securities No. 3416/BS-OPS/IV/2005 tanggal 18 April 2005 Perihal: Penawaran Tender Offer PT HM Sampoerna selaku Perusahaan Efek Yang ditunjuk oleh PT Philip Morris Indonesia.

2. Tahap Penyampaian Pernyataan Penawaran Tender

Pernyataan Penawaran Tender adalah suatu dokumen yang wajib disampaikan kepada Bapepam dan kepada pihak-pihak lainnya oleh pihak yang melakukan penawaran tender. Selambat-lambatnya pernyataan penawaran tender ini dilakukan lima hari sejak pengumuman rencana penawaran tender di dua surat kabar.

Pada kasus ini PT Philip Morris Indonesia sudah menyampaikan dokumen yang wajib disampaikan kepada Bapepam, Bursa Efek, dan Perusahaan Target. Hal ini dapat dilihat dari terbitnya surat dari KSEI yang menjelaskan untuk melaksanakan tender offer atas saham HMSP.

3. Tahap Efektifnya Masa Penawaran Tender

Masa penawaran tender menjadi efektif pada hari ker 15 (lima belas) sejak diterimanya pernyataan-pernyataan tender secara lengkap oleh Bapepam.

4. Tahap Pengumuman Pernyataan Penawaran Tender 
Dalam tahap ini, yaitu selambat-lambatnya 2 (dua) hari kerja sejak Pernyataan Penawaran Tender wajib diumumkan dalam sekurang-kurangnya dalam dua surat kabar harian.

Dalam tahap ini, pihak perusahaan target, pihak terafiliasi, dan lain-lain dapat mengajukan pernyataan tertulis yang salinannya wajib diserahkan ke Bapepam, yang berisikan informasi untuk mendukung atau menentang tender offer tersebut.

5. Tahap Bantahan dari Direksi/Komisaris Perusahaan Target Perusahaan target diwajibkan melakukan bantahan jika direksinya atau komisarisnya mengetahui bahwa pernyataan penawaran tender offer tersebut mengandung informasi yang tidak benar atau menyesatkan, dan bantahan tersebut wajib diumumkan dalam dua surat kabar harian dalam waktu paling lambat 15 hari sebelum berakhirnya tender.

Namun dalam kasus ini, tidak terdapat bantahan dari perusahaan target sehingga proses ini tidak terjadi pada kasus tender offer yang dilakukan atas saham HMSP.

6. Tahap Berakhirnya Masa Penawaran Tender

Masa penawaran tender berakhir sekurang-kurangnya dalam waktu 30 hari dan dapat diperpanjang untuk jangka waktu menjadi paling lama 90 hari, kecuali disetujui lain oleh Bapepam.

7. Tahap Penyelesaian Transaksi

Dalam tahap ini, yakni dalam jangka waktu paling lama 12 hari setelah penawaran berakhir, maka transaksi penawaran tender wajib diselesaikan. Yakni dengan penyerahan uang, penyerahan efek, atau dikembalikan efek yang telah ditenderkan dan sebagainya.

8. Tahap Laporan Akhir

Dalam waktu 10 (sepuluh) hari sejak tanggal penyelesaian penawaran tender berakhir, maka pihak yang melakukan tender offer tersebut wajib melaporkan hasil dari tender offer tersebut kepada Bapepam. 
Berdasarkan analisis di atas berdasarkan proses pelaksanaan tender offer, melalui surat pemberitahuan BEJ pada tanggal 3 Juni 2005 dinyatakan sah bahwa tender offer yang dilaksanakan oleh PT Philip Morris Indonesia telah dilaksanakan dan saham HMSP sebesar 98 \% dimiliki oleh PT Philip Morris Indonesia. Mengenai penetapan harga yang harus diatas dari harga bursa sudah dilakukan oleh PT Philip Morris Indonesia, karena pada saat itu, harga terakhir di saham HMSP sebesar Rp 8.850 dan Pt Philip Morris Indonesia membeli saham lebih mahal $20 \%$ di atas harga bursa yaitu sebesar Rp 10.600 .

\section{Penutup}

Ketentuan tentang benturan kepentingan transaksi tertentu yang terdapat dalam peraturan perundang-undangan pada prinsipnya adalah untuk melindungi hak setiap pemegang saham dalam melakukan transaksi apapun guna memperoleh keuntungan tertentu. Dalam kasus transaksi HMETD yang dilakukan oleh CPRO, CPRO tidak sepenuhnya mematuhi peraturan yang ada, karena masih terdapat pelanggaran terkait transaksi benturan kepentingan antara CPRO, SHS, dan PTPI, serta kewajiban penerapan prinsip disclosure dan fairness di pasar modal. Pelanggaran tersebut adalah tidak terpenuhinya kuorum kehadiran pemegang saham independen sebagaimana diatur dalam peraturan Bapepam Nomor IX.E.1 tentang Afiliasi dan Benturan Kepentingan Transaksi Tertentu, serta keterlambatan pengumuman tentang adanya addendum perjanjian utang piutang dengan SHS yang melanggar ketentuan peraturan Bapepam No. X.K.1 tentang Keterbukaan Informasi Material.

Dapat diketahui bahwa akuisisi yang telah terjadi pada PT. HM Sampoerna, Tbk tidak banyak menimbulkan perubahan baik itu dari segi pemasarannya maupun bagi karyawannya. Akuisisi yang dilakukan oleh PT. HM Sampoerna telah banyak menarik perhatian masyarakat bahkan pemerintah juga telah ikut mengambil langkah dalam hal kebijakan sehubungan dengan pelaksanaan akuisisi ini agar akuisisi tersebut 
dilakukan sesuai dengan peraturan yang berlaku. Pada dasarnya akuisisi ini sangat jarang terjadi pada sebuah perusahaan. Tujuan dilakukannya akuisisi ini tidak lain hanyalah untuk dapat menjadikan perusahaan tersebut menjadi perusahaan yang terbaik di mata masyarakat. Namun demikian pelaksanaan akuisisi ini harus benar benar memperhatikan ketentuaan hukum yang berlaku. Akuisisi yang telah dilakukan tersebut menjadikan hak para karyawannya lebih terjamin.

\section{Daftar Pustaka:}

Aliansyah, Rizky. "Perlindungan Hukum Terhadap Pemegang Saham Minoritas Dalam Penawaran Umum Terbatas Yang Mengandung Benturan Kepentingan (Studi Kasus Penawaran Umum Terbatas Dengan HMETD PT Central Proteinaprima Tbk)." Fakultas Hukum Universitas Indonesia, 2012.

Bapepam LK dan, Kementerian Keuangan RI. Master Plan Pasar Modal Dan Industri Keuangan Non-Bank 2010-2014, n.d.

Chairani, Tengku Lia. “'Dampak Akuisisi Antara PT. Philip Morris Indonesia Dengan PT HM Sampoerna Tbk Terhadap Status Karyawan PT HM Sampoerna Tbk Ditinjau Dari Segi Hukum Dagang."' Fakultas Hukum Universitas Sumatera Utara, 2006.

Fahmi, Irham. Pengantar Pasar Modal. Bandung: Alfabeta, 2012.

Fuady, Munir. Pasar Modal Modern: Tinjauan Hukum. Bandung: Citra Aditya Bakti, 1996.

M, Hendy. Go Public: Pendanaan Dan Peningkatan Nilai Perusahaan. Jakarta: Elex Media Komputindo, 2008.

Manan, Abdul. Hukum Ekonomi Syariah Dalam Perspektif Kewenangan Peradilan Agama. Jakarta: Kencana Prenada Media Grup, 2012.

Miller, Roger Leroy, and Frank B. Cross. Business Law:Alternate Edition (Twelfth Edition). Cengage Learning, 2013. 
Analisa Hukum Terhadap Benturan Kepentingan Dan Penawaran ...

Nasarudin, M. Irsan. Aspek Hukum Pasar Modal Indonesia. Jakarta: Kencana, 2008.

Nasution, Bismar. Keterbukaan Dalam Pasar Modal. Jakarta: Fakultas Hukum Universitas Indonesia Program Pascasarjana, 2001.

Okezone, pada ekonomi. “'Tender Offer."” http://economy.okezone.com/.

Riyatno, Bambang. Dasar-Dasar Pembelanjaan Perusahaan. Yogyakarta: BPFE Yogyakarta, 2001.

Sitompul, Asril. Pasar Modal, Penawaran Umum Dan Permasalahannya. Bandung: PT Citra Aditya Bakti, 2000.

Suta, I Putu Gede Ary. Menuju Pasar Modal Modern. Jakarta: Sad Satria Bhakti, 2000.

Tambunan, and Andy Porman. Menilai Harga Wajar (Stock Valuation). Jakarta: Gramedia, 2008.

vivanews. "Dalam Vivanews 'CP Prima Diminta Jelaskan Soal Right Issue.”' http://bisnis.news.viva.co.id/.

Winarto, Jasso. Pasar Modal Indonesia, Retrospeksi Lima Tahun Swastanisasi BEJ, Cet I,. Jakarta: PT. Jayakarta Agung Offset, 1997.

Yulfasni. Hukum Pasar Modal. Jakarta: Badan Penerbit IBLAM, 2005.

Keputusan Ketua BAPEPAM No. Kep-04/PM/2002. Peraturan No. Ix.F.1, Mengenai Penawaran Tender, n.d.

UU No. 40 Tahun 2007 tentang Perseroan Terbatas

UU No. 8 Tahun 1995 tentang Pasar Modal

Keputusan Ketua Bapepam No.KEP-32/PM/2000 tentang Perubahan Peraturan No.IX.E.1 tentang Benturan Kepentingan Transaksi Tertentu.

Keputusan Ketuan Bapepam No.KEP-86/PM/1996 Peraturan Bapepam No.X.K.1. tentang Keterbukaan Informasi. 
Keputusan Ketua Bapepam-LK No.KEP-521/BL/2008 Peraturan No.IX.E.1 tentang Transaksi Afiliasi dan Benturan Kepentingan Transaksi Tertentu.

Keputusan Ketua Bapepam No.KEP-412/BL/2009 Peraturan No.IX.E.1 tentang Benturan Kepentingan transaksi tertentu.

Keputusan Ketua Bapepam No.KEP-04/PM/2002 Peraturan No.IX.F.1 tentang Penawaran Tender.

Keputusan Ketua Bapepam No.KEP-04/PM/2000 Peraturan No.IX.H.1 tentang Pengambil Alihan Perusahaan Terbuka.

Detikfinance, "Philip Morris Akan Akuisisi 40 Persen Saham HM Sampoerna," dalam http://finance.detik.com/

Emirzon, Joni. Hukum Bisnis Indonesia, Proyek Peningkatan Penelitian Pendidikan Tinggi Direktorat Jenderal Pendidikan Tinggi Departemen Pendidikan Nasional, 2002.

Kementerian Keuangan RI dan Bapepam LK. "Master Plan Pasar Modal dan Industri Keuangan Non-Bank 2010-2014"

Pengkajian Hukum Akuisisi Perusahaan, Jakarta Yayasan Pusat Pengkajian Hukum, 1992. 